\title{
Occurrences and Characteristics of Gold Mineralization in Rampi Block Prospect, North Luwu Regency, South Sulawesi Province, Indonesia
}

\author{
Arifudin Idrus ${ }^{* 1}$, Suaib Mansur ${ }^{2}$, Ahmad $^{2}$, Rahmayuddin $^{2}$, and Abdul Mahdi ${ }^{2}$ \\ ${ }^{1}$ Department of Geological Engineering, Faculty of Engineering, Gadjah Mada University, Indonesia \\ ${ }^{2}$ Mining and Energy Agency, North Luwu District, South Sulawesi Province, Indonesia
}

\begin{abstract}
This study is aimed to identify the occurences, characterisatics and genetic type of gold mineralization, and to elucidate the preliminary gold potential in the study area. Research method includes field observation of prospect geology, hydrothermal alteration and ore mineralization. Laboratory analysis consists of petrography, ore microscopy and ore chemistry. Geologically, quartz \pm gold veins were found in Rampi block prospect, which are mainly hosted by metamorphic and metasediment rocks. The quartz veins has structurally segmented with massive, brecciated and laminated textures. Orientation and distribution of veins is controlled by NW-SE and NE-SW trending structures. Sulfides are present with minor abundance $(<1 \%)$. Pyrite is obviously observed and partially oxidized. Arsenopyrite and stibnite are minor, while basemetal $(\mathrm{Pb}, \mathrm{Zn})$ sulfides are very rare. Gold mineralization occurred in quartz veins and closely related to silica-clay and silicic alteration. Gold grade varies from 0.1 to $11 \mathrm{ppm} \mathrm{Au} \mathrm{(29} \mathrm{samples).} \mathrm{Quartz} \mathrm{veins} \mathrm{contained} \mathrm{high}$ gold grade $(>9 \mathrm{ppm})$ commonly show laminated and brecciated texture and has been undergone a supergene enrichment. According to several characteristics above, gold deposit in Rampi block prospect tends to meet the criteria of orogenic/mesothermal gold type (cf. Groves et al., 2003). The deposit shares similarities with Awak Mas prospect, which is already confirmed to be a mesothermal type in Luwu district (cf. Querubin and Walters, 2011). Therefore, discoveries of economic mesothermal gold deposits are still open in the metamorphic terrains, and thus, it requires a systematic exploration based on the genetic model of the deposit.
\end{abstract}

Keywords: Gold · Orogenic/mesothermal · Rampi block prospect · North Luwu · Sulawesi · Indonesia.

\section{INTRODUCTION}

The needs and metal prices, especially precious metal and base metal in the world market are steadily increasing, "forcing" us to conduct an inventory, exploration and extraction of those metal deposits. Moreover, with the implementation of regional autonomy and decentralized management of mineral deposits, the exploration activities become vital in planning and resource utilization policy to improve the regional economy. For example, North

\footnotetext{
${ }^{*}$ Corresponding author: A. IDRUS, Department of Geological Engineering, Faculty of Engineering, Gadjah Mada University. Jl. Grafika 2 Yogyakarta, Indonesia. Email: arifidrus@ugm.ac.id
}

Luwu Regency, located in northern part of Sulawesi Province, are the area with the potential of ore mineral resources, which are dominated by gold hosted by metamorphic rock, volcanic rock and sedimentary/metasediment rocks. Commonly, gold mineralization is associated with quartz vein. With this background, a study was conducted with the focus on distribution and characterisation of ore mineralization and interpretation of ore deposit origin. The research is focused on Rampi block prospect (Figure 1). The objectives of this study are to provide an overview of occurrences, characteristics, deposit type and potential of gold mineralization in research area and as support- 


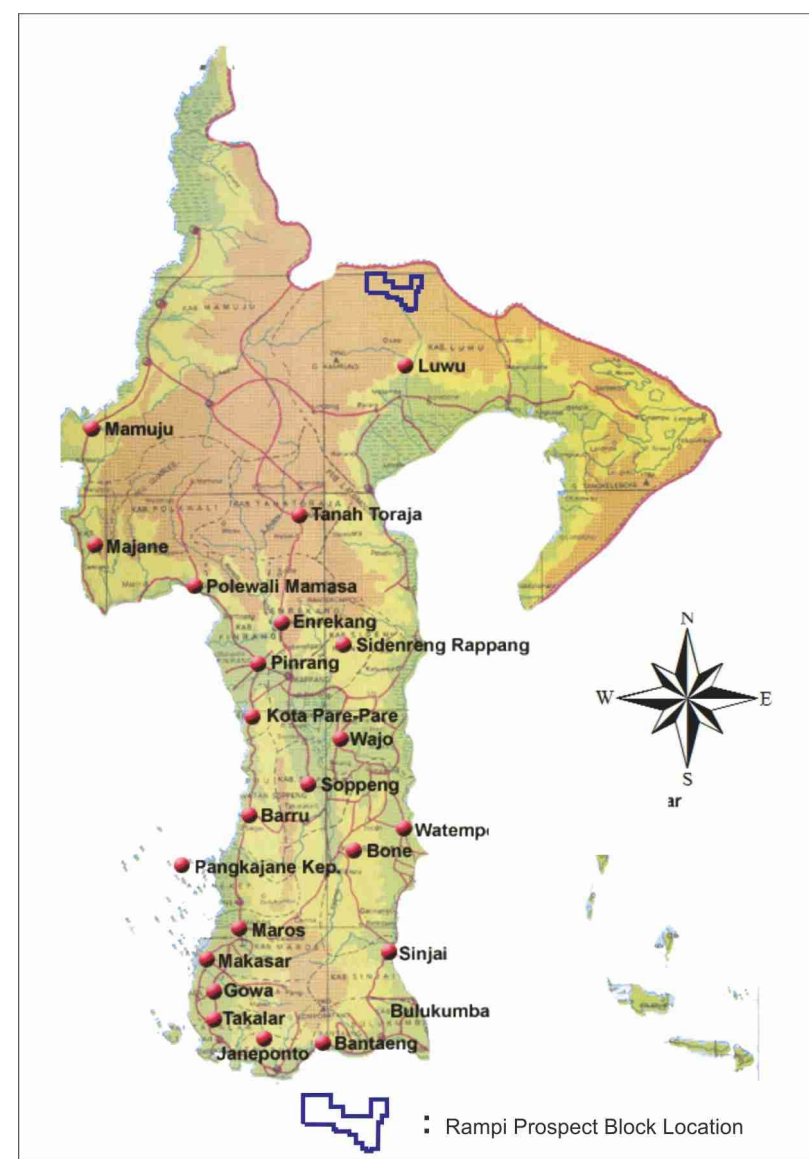

Figure 1: Research area (Rampi block prospect) in Rampi sub-district, North Luwu regency located in northern part of South Sulawesi province.

ing information for exploration activities and development of ore mineral resources in the region.

\section{Regional Geology}

Rampi block prospect area is a plateau that extends from east to west. The highest peak of the mountain in the area is Temaduri Mountain $(2,074 \mathrm{~m})$. Among these mountains, lies rivers which commonly flow to Lariang River and Toboru River. Regional stratigraphy of research area refers to the Geological Map of Malili sheet (Simandjuntak et al., 1991) (Figure 2). Regionally, Rampi area is occupied by various lithologies from oldest to youngest including Pompangeo Complex (MTmp), Latimojong (Kls), Kambuno Granite (Tpkg), Rampi Tuff Formation (Tmrt), Tineba Volcanic Rock (Tmtv) and Alluvium (Qal).

Pompangeo metamorphic rock complex (MTmp) is the oldest formation in the study area that consists of schist, gneiss, marble, serpentinite and metaquartzite, slate, phyllite and breccia. Latimojong Formation (Kls) is comprised of interbedded of slate, phyllite, wake, limestone, quartzite and siltstone intercalated with conglomerate and chert. Kambuno granite (Tpkg) consists of granite and granodiorite. Based on its lithological similarity with granite in Pasangkayu map sheet, the Kambuno granite is estimated to be formed at 3.35 million years ago (Pliocene). Rampi tuff formation (Tmrt) is composed of tuffaceous sandstone, grey tuff and crystal tuff. This Formation is unconformably deposited on Latimojong Formation and inter fingering with Tineba Volcanic Rock (Tmtv). Tineba Rock Volcanic consists of hornblende andesite lava, basalt, quartz latitte and breccia. This formation occupies Tineba plateau that extends northward Rampi area in northwestern part of Malili geological map. Alluvium (Qal) is composed of river, swamp and coastal deposits.

\section{RESEARCH METHODS}

Fieldwork methods applied to achieve the objectives of research consist of geological and hydrothermal alteration observation. Rock and ore samples were collected for various laboratory analyses. Laboratory analysis includes mineralogical and ore geochemical analyses. Mineralogical analysis was performed for 15 thin sections and 5 polished sections using polarized- and reflected-light microscopes, respectively, at Mineral Resources laboratory, Department of Geological Engineering, Gadjah Mada University. Altered rock and ore petrography was described based on Thomson and Thomson (1996) and Marshall et al. (2004), respectively. Twenty ore samples were analysed using AAS (Atomic Absorption Spectrometry) at Energy and Mineral Resources (ESDM) Agency of South Sulawesi province, where 9 ore samples were analysed using AAS at Intertek Utama Services laboratory in Jakarta. Both fieldwork and laboratory analytical data were integrated and interpreted to achieve the objectives of research. 


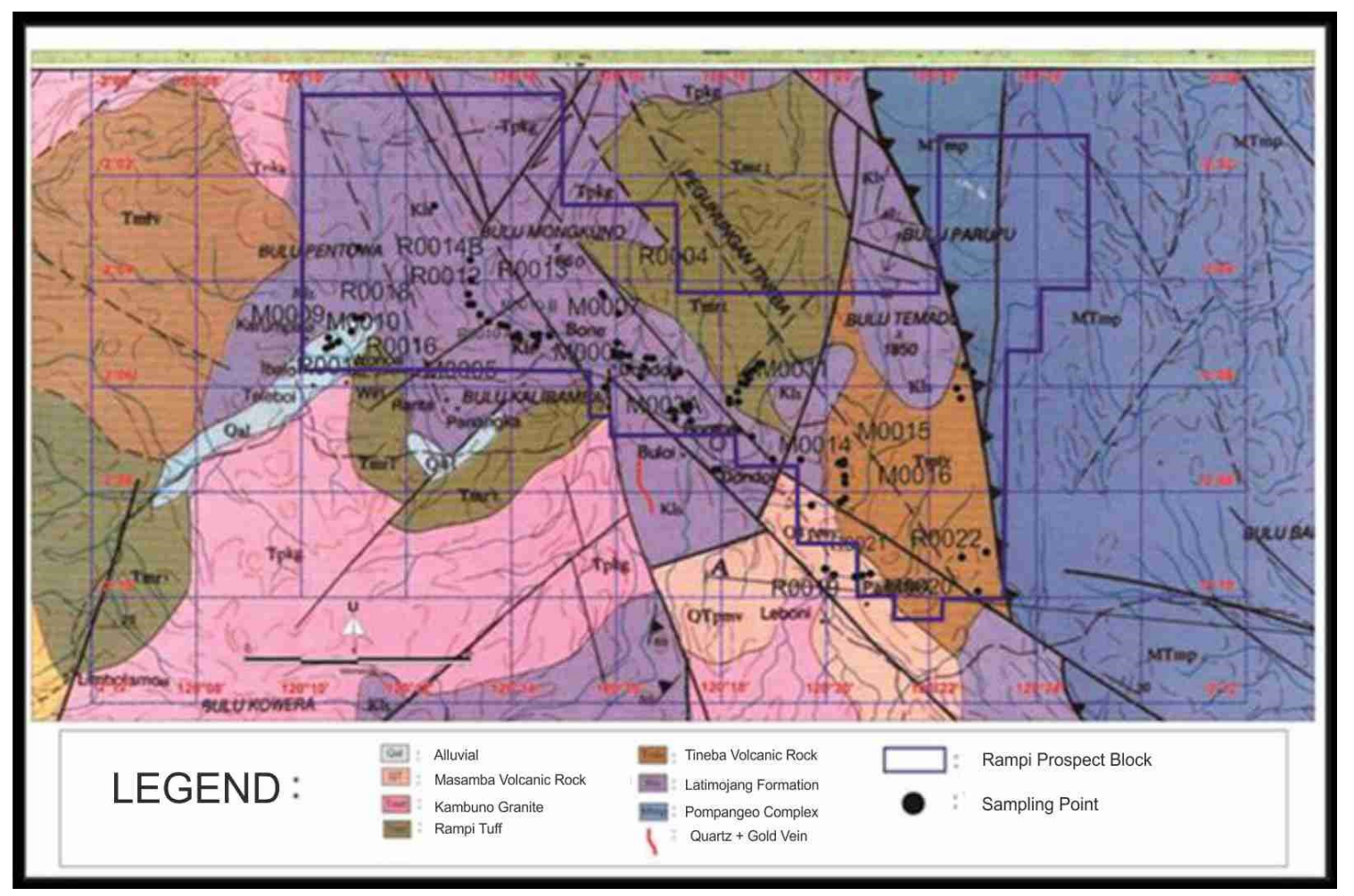

Figure 2: Regional geological map of Rampi block prospect area with 25.000 Ha plotted on Geological map of Malili, Majene, and western part of Palopo sheet (Simandjuntak et al, 1991). Sampling points and quartz veins are indicated on the map.

\section{RESUlTS AND DisCUSSION}

\section{Geology of the study area}

On the basis of regional geology and geological observation, the studied area is predominantly occupied by sedimentary rock/metasedimentary rocks from Latimojong formation (Kls), and a wide variety of volcanic rocks including tuffs, breccias and andesite lava from Rampi tuff formation (Tmrt) and Tineba volcanic rock formation (Tmtv). Schists, gneiss, marble, serpentinite, meta- quartzite, phyllite and slate, members of the Pompangeo complex (MTmp) are exposed in the eastern part of the research area. Gold mineralization and base metals are found in the form of quartz veins hosted by metamorphic/sedimentary rocks/metasedimentary rock (Latimojong formation), volcanic rocks (tuff) and also possibly hosted in the Pompangeo metamorphic complex. Geological structures particularly NW-SE, NE-SW trending strike slip faults were interpreted to be a part of major PaluKoro fault orders. The strike-slip faults were probably the main geological aspect controlling the formation of gold mineralization in the research area.

\section{Hydrothermal alteration}

Hydrothermal alteration types developed in research area consist of propylitic alteration (chlorite - epidote - calcite), argillic alteration (clay mineral) and silicification zone (quartz - clay). Field Observation indicates that ore mineralization in form of gold-bearing quartz veins are mostly enveloped by sillification and argillic zone. However, in some cases, quartz veins can be associated with propylitic alteration. In general, prophyllitic zone developed in the periphery of the mineralization system. Outcrop and petrographic microphotograph of silicified and propylitic altered rocks are seen in Figure 3 .

\section{Characteristics of gold mineralization}

Ore mineralization in Rampi block prospect occurred in the form of quartz veins containing gold and other metals and disseminated in wallrocks around the vein. The quartz vein are commonly segmented with massive, brecciated and laminated textures (Figure $4 \mathrm{~A}-\mathrm{D}$ ). Quartz veins are enveloped by silica-clay and silicified altered wallrock. Several quartz veins are hosted by prophyllitic altered rock. Quartz veins found in small scale mining at 

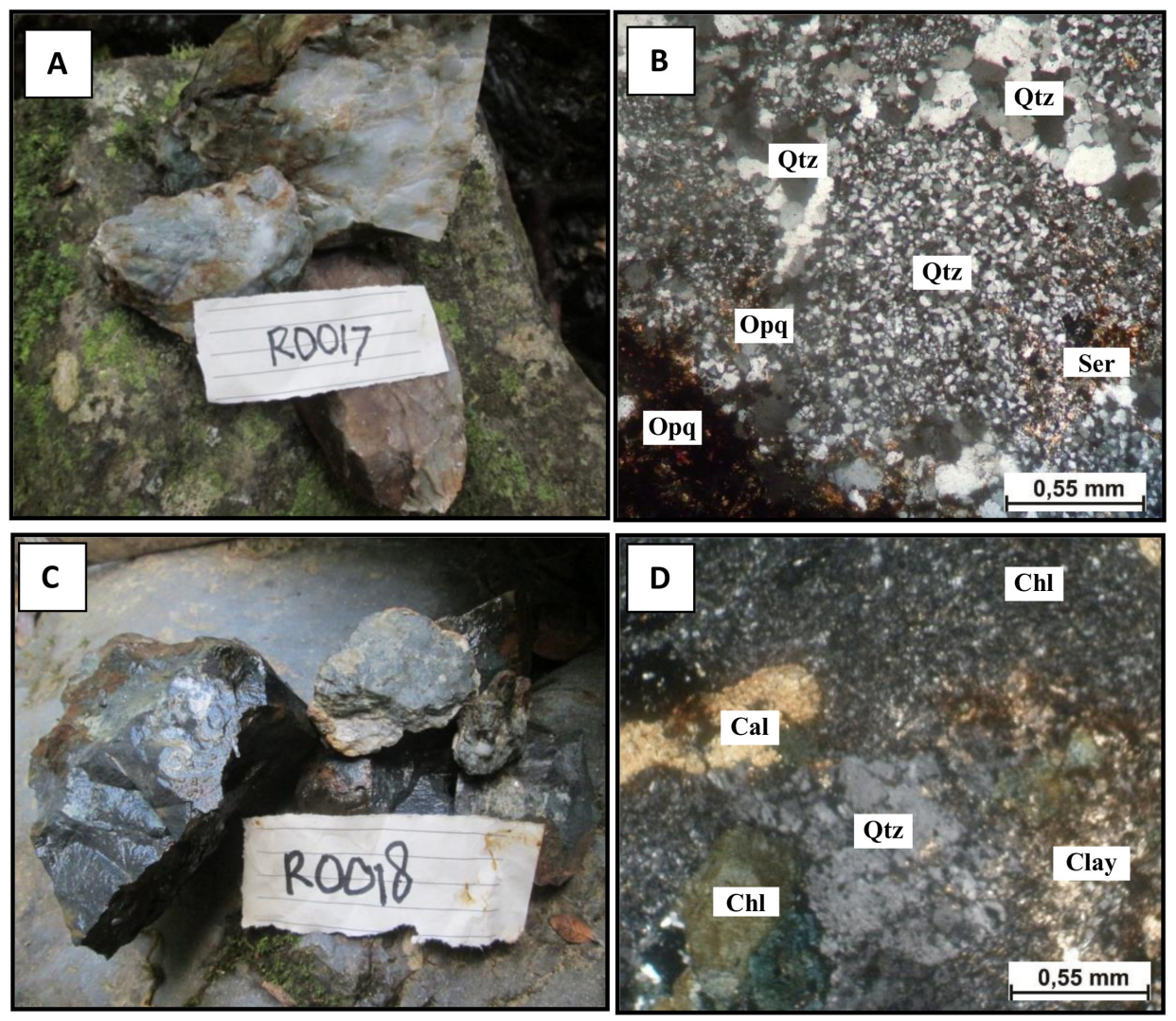

Figure 3: Outcrop/handspecimen and petrographic microphotograph of altered wall rocks in Rampi block prospect: (A) and (B) silicified rock; (C) and (D) propylitic altered rock.

Tomonongka River and Salman Tunnel show typical characteristics of strongly brecciated, remnant texture of host rock is not observable due to pervasive alteration, chalcedonic quartz, fine grained, granular shape and minor cavities filled by pyrite. Some quartz veins have beeen brecciated where chalcedonic quartz as fragment and clay mineral as matrix. They are commonly oxidized (limonitization) indicating a supergen enrichment process. Strong oxidized brecciated and laminated quartz veins contain high grade of gold. For instance, brecciated and limonitized quartz vein (Figure $4 \mathrm{C}$ ) contains 11 ppm Au, low base metal content, 959 ppm Ag, 95 ppm As and 270 ppm Sb. Laminated quartz vein (Figure 4D) contains 10 ppm Au, low basemetal (Cu, PB, Zn), 125 ppm $\mathrm{Ag}$, $80 \mathrm{ppm}$ As and 75 ppm Sb. Generally, the sulfide abundance are minor $(<1 \%)$, pyrite is partially converted to hematite. Arsenopyrite and stibnite may be present in minor portion in form of very fine-grained, which is proven by a significant content of $\mathrm{As}$ and $\mathrm{Sb}$ in the vein.

\section{Ore chemistry}

Based on geochemical analysis of 21 samples of ore veins/rock, gold grade in quartz vein occurred in studied area varies between $0.01 \mathrm{ppm}$ to $3.57 \mathrm{ppm}$. The highest gold grade $(3.57 \mathrm{ppm}$ $\mathrm{Au}$ ) was detected in the Sample 062B, and in the Sample 060B (2.82 ppm Au), while Samples 052B, 053B, 061B, 063B, 064B, 065B, 070B, 074B and $074 \mathrm{~B}$ has gold grade ranging from 0.53 to $0.71 \mathrm{ppm}$. Other samples contain gold between $0.01 \mathrm{ppm}$ and $0.17 \mathrm{ppm}$ or less. Highest copper $(\mathrm{Cu})$ is $127.73 \mathrm{ppm}$ contained by Sample 074B, and the highest grade of $\mathrm{Pb}$ and $\mathrm{Zn}$ reaching $150.70 \mathrm{ppm}$ and $94.89 \mathrm{ppm}$, respectively is contained by Sample 056B (Table 1).

In addition, AAS assay result of 9 vein/rock samples from the artisanal mine site (Tomonongka and Salman river tunnel) shows gold grade of the research area varying between $0.06 \mathrm{ppm}$ to the highest of $11 \mathrm{ppm}$ (Table 1). An elevated gold content (11 ppm) was detected in Sample 370220, Sample 370208 (10 ppm Au) and Sample 370222 (9.98 ppm $\mathrm{Au})$. The lowest gold of $0.06 \mathrm{ppm}$ is contained by Sample 370206. Interestingly, the highest 
Table 1: AAS assay of gold and associated elements in quartz vein and mineralized rock samples from Rampi block prospect, North Luwu district, South Sulawesi (in ppm).

\begin{tabular}{|c|c|c|c|c|c|c|c|c|c|}
\hline No. & Sample & $\mathrm{Au}$ & Ag & $\mathrm{Sb}$ & As & $\mathrm{Hg}$ & $\mathrm{Cu}$ & $\mathrm{Zn}$ & $\mathbf{P b}$ \\
\hline 1 & 052B & 0.71 & 0.05 & na & na & na & 40.7 & 53.08 & 47.89 \\
\hline 2 & 053B & 0.71 & 0.06 & na & na & na & 10.6 & 51.83 & 36.6 \\
\hline 3 & 054B & 0.53 & 0.33 & na & na & na & 78.68 & 15.79 & 56.36 \\
\hline 4 & 055B & 0.08 & 0.12 & na & na & na & 68.93 & 14.07 & 44.3 \\
\hline 5 & 056B & 0.1 & 0.3 & na & na & na & 43.11 & 94.89 & 150.7 \\
\hline 6 & 057B & 0.04 & 0.1 & na & na & na & 11.41 & 38.85 & 50.91 \\
\hline 7 & 058B & 0.69 & 6.12 & na & na & na & 12.22 & 85.59 & 40.19 \\
\hline 8 & 059B & 17 & 0.06 & na & na & na & 63.73 & 61.77 & 35.51 \\
\hline 9 & 060B & 2.82 & 0.07 & na & na & na & 47.65 & 66.31 & 34.08 \\
\hline 10 & 061B & 0.71 & 0.06 & na & na & na & 9.36 & 33.22 & 40.02 \\
\hline 11 & 062B & 3.57 & 0.07 & na & na & na & 13.61 & 87.06 & 36.63 \\
\hline 12 & 063B & 0.7 & 0.06 & na & na & na & 37.38 & 53.56 & 46.15 \\
\hline 13 & 064B & 0.69 & 0.01 & na & na & na & 45.96 & 30.76 & 40.02 \\
\hline 14 & 065B & 0.7 & 0.21 & na & na & na & 39.94 & 22.43 & 34.01 \\
\hline 15 & 066B & 0.12 & 0.08 & na & na & na & 78.68 & 80.09 & 45.88 \\
\hline 16 & 070B & 0.7 & 0.01 & na & na & na & 14.17 & 46.9 & 39.98 \\
\hline 17 & 071B & 0.01 & 0.04 & na & na & na & 79.07 & 40.28 & 33.84 \\
\hline 18 & 072B & 0.01 & 0.01 & na & na & na & 7.93 & 21.7 & 53.2 \\
\hline 19 & 073B & 0.01 & 0.01 & na & na & na & 4.06 & 21.34 & 58.19 \\
\hline 20 & 074B & 0.7 & 0.06 & na & na & na & 127.73 & 43.73 & 47.24 \\
\hline 21 & 370202 & 0.07 & - & 79 & - & - & na & na & - \\
\hline 22 & 370204 & 1 & - & - & 53 & - & na & na & 99 \\
\hline 23 & 370205 & 0.29 & - & - & - & - & na & na & - \\
\hline 24 & 370206 & 0.06 & - & - & 72 & - & na & na & - \\
\hline 25 & 370208 & 10 & 125 & 75 & 80 & - & na & na & - \\
\hline 26 & 370215 & 2.08 & 25 & 64 & 160 & - & na & na & 89 \\
\hline 27 & 370220 & 11 & 959 & 270 & 95 & - & na & na & - \\
\hline 28 & 370221 & 1.39 & - & 31 & 14 & - & na & na & 71 \\
\hline 29 & 370222 & 9.98 & 84 & 97 & 56 & 19 & na & na & 27 \\
\hline
\end{tabular}

Note: na $=$ not analysed

- $=$ not detected 

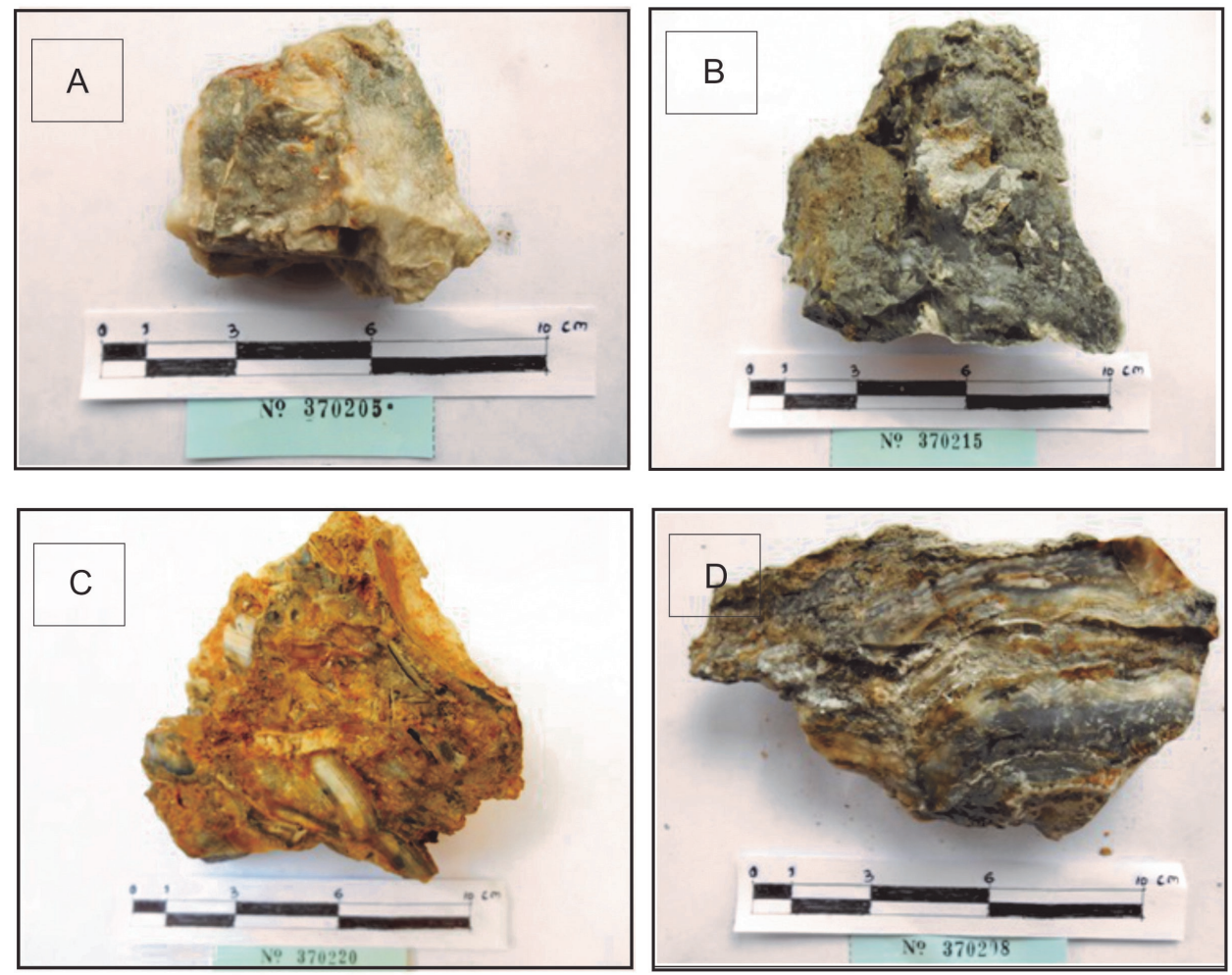

Figure 4: Types and textures of chalcedonic-quartz vein containing significant gold found in Rampi block prospect, North Luwu district: (A) Massive chalcedonic quartz vei, (B) Brecciated quartz vein, (C) Brecciated and oxidized (limonitized) quartz vein, and (D) Laminated chalcedonic quartz vein.

$\mathrm{Sb}(270 \mathrm{ppm})$ is contained by Sample 370220, whereas the highest As is found from Sample 370215 (160 ppm). Hg content is only detected in Sample 370202 (19 ppm). Copper, $\mathrm{Pb}$ and $\mathrm{Zn}$ contents are relatively low, ranging between 4 to $127 \mathrm{ppm} \mathrm{Cu}, 27-150 \mathrm{ppm} \mathrm{Pb}$, and 14.7-94.9 ppm Zn, respectively. Generally, gold mineralization at Salman tunnel is characterized by silica-clay altered and weakly oxidized rock/zone of chalcedonic quartz (as fragment) and clay minerals (as matrix). Gold ( $\mathrm{Au}$ ) tends to be intimately associated with $\mathrm{Sb}$, As and $\mathrm{Hg}$, not to basemetals such as $\mathrm{Cu}, \mathrm{Pb}$ and $\mathrm{Zn}$. Gold content is relatively high and typically varies from 0.01 to $11 \mathrm{ppm}$. In addition, high gold content is also hosted by strongly oxidized quartz veins, which may suggest the important role of supergene enrichment processes.

\section{Discussion: Mineralization style and gold po- tential}

Currently, in Indonesia gold is mostly mined from volcanic-hosted hydrothermal deposit types including LS-epithermal type e.g. Pongkor in West Java (Warmada, 2003) and Gosowong in Halmahera Island, skarn type e.g. Erstberg, Kucing Liar and Deep Ore Zone (DOZ) in Papua, and porphyry type e.g. Batu Hijau in Sumbawa Island (Idrus et al., 2007; Imai \& Ohno, 2005) and Grasberg in Papua. In Sulawesi Island, gold mineralization is also predominantly related to volcanic rocks, which are extended along western and northern Neogene magmatic arcs of the island (Idrus, 2009). As outlined above, however, gold prospects have also been recognized in Rampi block prospect, North Luwu district, South Sulawesi province. Gold mineralization in Rampi block prospect is in form of quartz \pm gold veins are mainly hosted by metamorphic/metasediment rocks of Latimojong formation and Pompangeo metamorphic rock complex.

On the basis of this study, gold-bearing quartz vein found are commonly segmented, occasionally brecciated and laminated in structure and has massive texture. It contains rarely sulfide minerals $(<1 \%)$, which only pyrite been observed, arsenopyrite and stibnite may be present in very fine-grained size. Rare sulfide was also observed in gold-bearing quartz veins in Bombana, Southeast Sulawesi (Idrus \& Prihatmoko, 2011), Gunung Butak, Buru 
Island (Idrus et al., 2014) and Awak Mas in Luwu (Querubin \& Walters, 2011; Harjanto et al., 2015). Gold grade in quartz veins are very erratic, with the highest gold grade is 11 ppm with elevated grade of $\mathrm{As}$ and $\mathrm{Sb}$ are 270 and $160 \mathrm{ppm}$, respectively. Basemetal $(\mathrm{Cu}, \mathrm{Pb}$, $\mathrm{Zn}$ ) content in the quartz vein is relatively low compared to those in typical LS-epithermal gold-bearing quartz vein. Based on some genetic characteristics described above, goldbearing quartz vein in the prospect area tends to meet the criteria of mesothermal (orogenic) gold type, which may be plotted into epizonalmesozonal of orogenic continuum models (cf. Groves et al., 2003). The discovery of goldbearing quartz veins (lode gold) contained significant gold grade hosted by metasediment/metamorphic rocks in studied area, as well as the lesson learned from discovery of the nearest confirmed orogenic (mesotermal) gold prospect in Awak Mas, Luwu district (Querubin \& Walters, 2011; Harjanto et al., 2015), it implies that the potential and opportunities to discover economic gold deposits in this region is very open. This absolutely needs a systematic exploration activity by considering efficient, effective and cost-benefit principles.

\section{CONCLUdING REMARKS}

Chalcedonic gold-bearing quartz veins discovered in several locations within Rampi block prospect are hosted by metamorphic rocks, meta-sedimentary rocks and sedimentary rocks mainly of Latimojong formation and Pompangeo metamorphic complex. The quartz veins are generally segmented structure with typically massive, brecciated and laminated/banded textures. No open space filling textures of quartz veins were observed. Orientation and distribution of veins is controlled by NW-SE and NE-SW trending transcompressional structures that might regionally be interpreted to be a part of major Palu-Koro fault orders. The strike-slip faults were probably the main geological aspect controlling gold mineralization in the research area.

Ore mineralization is characterized by rare sulfides $(<1 \%)$, but fine-grained pyrite was observed and partly has been oxidized to hematite. Other sulfides such as arsenopyrite and stibnite may also be present in very fine- grained size. Basemetal sulfides including very fine-grained chalcopyrite, galena and sphalerite are present in very minor. Hydrothermal alteration is characterized by the presence of silica-clay, silicification and propylitic type. Ore mineralization is closely associated with silica-clay and silicic alteration.

Ore chemical analysis of 29 selected mineralized quartz veins indicates that gold greatly varies (erratic) ranging between 0.1 and $11 \mathrm{ppm}$ $\mathrm{Au}$. Gold-bearing quartz veins contained elevated gold of more than 9 ppm Au are generally characterized by laminated/banded and brecciated textures and has partially been oxidized/limonitized (Fe-rich sulfides converted to hematite/goethite). Gold grade may be upgraded through supergene enrichment process.

On the basis of those studied genetic characteristics, quartz veins/lode gold/reef discovered in Rampi block prospect tends to meet the criteria orogenic/mesothermal gold type (cf. Groves et al., 2003). Orogenic/mesothermal gold in this area is controlled by NW-SE and NE-SW trending strikeslip (trans-compressional) structures and typically hosted by metasediment/metamorphic rocks of Latimojong formation. The same geological framework also controlled the formation of the nearest confirmed mesothermal gold prospect i.e. Awak Mas in Luwu district (cf. Querubin \& Walters, 2011; Harjanto et $a l ., 2015)$. This suggests that the metamorphic rock-hosted lode gold is still open to discover in this region through a systematic exploration program.

\section{ACKNOWLEDGEMENTS}

This study was funded by Mining and Energy Agency of North Luwu Regency through Rampi block prospect survey project with Contract No.: 546/XX/2015/Distamben, which was fully financed through APBD 2015 fiscal year. Therefore, we would like to express our deep gratitude for their financial support and cooperation. Many thanks and appreciation also goes to Rampi survey team who already worked hard to serve the data for this project.

\section{REFERENCES}

Groves, D. I., Goldfarb, R. J., and Robert, F. (2003) Gold deposit in metamorphic belts: Overview or current understanding, outstanding problems, 
future research, and exploration significance. Economic Geology 98: 1-29.

Harjanto, E., Meyer, F.M., Idrus, A. (2015) Geology and Mineralization of Awak Mas Gold Deposit and Challenges for New Exploration Targeting in the Metamorphic Rock Terrain of Eastern Indonesia, 13th SGA Meeting, Nancy, France, 24-27 August, 2015, p. 103-106.

Idrus, A., Kolb, J., Meyer, F.M. (2007) Chemical composition of rock-forming minerals in coppergold-bearing tonalite porphyry intrusions at the Batu Hijau deposit, Sumbawa Island, Indonesia: Implications for crystallisation conditions and fluorine-chlorine fugacity, Special Issue, Resource Geology 57: 102-113.

Idrus, A., Warmada, I.W., Setyawan, I., Raditya, B., Kurnia, M. (2009) Endapan Urat Epitermal di Tirtomoyo, Kabupaten Wonogiri, Propinsi Jawa Tengah: Studi Awal mengenai Alterasi Hidrotermal, Mineralisasi Bijih dan Inklusi Fluida. Majalah Geologi Indonesia 24(1): 13-20.

Idrus, A., and Prihatmoko, S. (2011) The metamorphic rock-hosted gold mineralization at Bombana, Southeast Sulawesi: A new exploration target in Indonesia, Proceedings of The Sulawesi Mineral Seminar, Manado 28-29 November 2011, p. 243-258.

Idrus, A., Sufriadin, Nur, I. (2011) Hydrothermal Ore Mineralization in Sulawesi: A Point of View of Tectonic Setting and Metallogenesis, Proceeding JCM Makassar 2011, The 3th HAGI and 40th IAGI Annual Meeting, Makassar 26-29 September 2011, p. 298-310
Idrus, A., Prihatmoko, S., Hartono, H.G., Fadlin, Ernowo, Franklin, Moetamar, Setiawan, I. (2014) Some key features and possible origin of the metamorphic rock-hosted gold mineralization in Buru island, Indonesia. Indonesian Journal on Geoscience 1(1): 9-19.

Imai, A. and Nagai, Y. (2009) Fluid inclusion study and opaque mineral assemblage at the deep and shallow part of the Batu Hijau porphyry $\mathrm{Cu}-\mathrm{Au}$ deposit, Sumbawa, Indonesia. Resource Geology, 59: 231-243.

Marshall, D., Anglin, C.D., Mumin, H. (2004) Ore Mineral Atlas, Geological Association of Canada, Mineral Deposits Division, St. Johns Newfoundland, $112 \mathrm{p}$.

Querubin, C.D., and Walters, S. (2011) Geology and Mineralization of Awak Mas: A Sedimentary Hosted Gold Deposit, South Sulawesi, Indonesia, Proceedings of The Sulawesi Mineral Seminar, Manado 28-29 November 2011, p. 211-229.

Simandjuntak, T.O., Rusmana, Surono, Supanjono (1991) Peta Geologi Lembar Malili, Majene dan Palopo Bagian Barat, P3G Bandung.

Thomson, A.J.B., Thomson, J.F.H. (1998) Atlas of Alteration, A Field and Petrographic Guide to Hydrothermal Alteration Minerals, Geological Association of Canada, Mineral Deposits Division, St. Johns Newfoundland, $119 \mathrm{p}$.

Warmada, I W. (2003) Ore mineralogy and geochemistry of the Pongkor epithermal gold-silver deposit, Indonesia, Dissertation. Papierflieger, Clausthal-Zellerfeld. 